\title{
Effects of organic amendments on soil properties and growth characteristics of Melon (Cucumis melo L.) under saline irrigation
}

\author{
Mohammed M. A. Elbashier ${ }^{1 *}$, Yalu Shao ${ }^{2,3^{*}}$, Liangkai Wang ${ }^{1}$, Deli Chen ${ }^{3}$, Hua Zhong ${ }^{2}$ \\ (1. College of Agricultural Sciences and Engineering, Hohai University, Nanjing 210098, China; \\ 2. State Key Laboratory of Water Resources and Hydropower Engineering Science, Wuhan University, Wuhan 430072, China; \\ 3. School of Agriculture and Food, The University of Melbourne, Victoria 3010, Australia)
}

\begin{abstract}
Establishing strategies of organic amendments application to mitigate the adverse effects of saline irrigation are essential for the sustainable agriculture. A two-year pot experiment was conducted using combinations of organic amendments including effective microorganisms (EM), biochar (BC) and digestate (Di) to investigate their effects on soil and melon (Cucumis melo L.) compared with the recommended NPK fertilizer and Control (CK) under two levels of irrigation water salinity (SL0: $0.25 \mathrm{dS} / \mathrm{m}$, SL1: $2.0 \mathrm{dS} / \mathrm{m}$ ). Results showed combined applications of organic amendments could significantly $(p<0.05)$ increase soil $\mathrm{pH}$ and organic matter $(\mathrm{OM})$ compared to NPK and CK. Application of organic amendments containing BC evidently increased the sodium adsorptive capacity (SAC) under saline water solution. The combined application of $\mathrm{EM}, \mathrm{BC}$ and $\mathrm{Di}(\mathrm{EM}+\mathrm{BC}+\mathrm{Di})$ could significantly $(p<0.05)$ improve soil available water retention under SL0 and SL1 compared with other treatments. Results also showed organic amendments application can significantly $(p<0.05)$ enhance the photosynthetic rate $(\mathrm{Pr})$ and reduce sodium ion $\left(\mathrm{Na}^{+}\right)$content in melon leaves. $\mathrm{EM}+\mathrm{BC}+\mathrm{Di}$ could significantly $(p<0.05)$ increase water use efficiency (WUE) and fruit yield of melon under SL0 and SL1 in comparison to other treatments. It proved that $\mathrm{EM}+\mathrm{BC}+\mathrm{Di}$ had a positive effect on soil improvement, melon growth, WUE and fruit yield. Moreover, $\mathrm{EM}+\mathrm{BC}+\mathrm{Di}$ could be used as an alternative strategy for mineral NPK fertilization of melon at reasonable dosages and frequencies under saline irrigation.
\end{abstract}

Keywords: organic amendments, saline irrigation, soil improvement, melon, water use efficiency DOI: $10.25165 /$ j.ijabe.20211405.6607

Citation: Elbashier M M A, Shao Y L, Wang L K, Chen D L, Zhong H. Effects of organic amendments on soil properties and growth characteristics of Melon (Cucumis melo L.) under saline irrigation. Int J Agric \& Biol Eng, 2021; 14(5): 123-129.

\section{Introduction}

Salt stress is one of the most serious limiting factors for crop growth and production in the arid, semiarid and coastal regions ${ }^{[1]}$. About $23 \%$ of the world's cultivated areas are saline due to man-made processes such as saline irrigation ${ }^{[2]}$. There are many successful trials to utilize saline water resource for crop production, including direct irrigation with saline water ${ }^{[3]}$, mixed irrigation with freshwater and saline water ${ }^{[4]}$, irrigation with freshwater and saline water in rotation ${ }^{[5,6]}$. Organic amendments are considered as one of the possible solutions to increasing crop growth. They had a significant role in enhancing soil properties and avoiding harmful effects of salt stress ${ }^{[7]}$.

Excessive chemical fertilization usually leads to soil salinity increase $^{[8]}$. Recent researches adopted the traditional fertilization

Received date: 2021-03-22 Accepted date: 2021-07-06

Biographies: Liangkai Wang, $\mathrm{PhD}$, research interests: agricultural environmental engineering, Email: wangliangkai93@163.com; Deli Chen, Professor, research interests: water and nutrient dynamics in plant-soil systems, Email: delichen@unimelb.edu.au; Hua Zhong, Professor, research interests: remediation of contaminated soil and water environment. Email: zhonghua21cn@126.com.

*Corresponding author: Mohammed M. A. Elbashier, PhD, research interests: agricultural water and soil engineering, College of Agricultural Sciences and Engineering, Hohai University, Nanjing 210098, China, Tel: +86-25-83786925, Email: mohammedltr@hotmail.com; Yalu Shao, PhD candidate, research interests: remediation of contaminated soil and water environment, State Key Laboratory of Water Resources and Hydropower Engineering Science, Wuhan University, Wuhan 430072, China. Tel: +86-27-68772215, Email: shaoyalu@hotmail.com. practices to improve soil organic inputs by using organic amendments $^{[9,10]}$. Biochar (BC) is a carbon-rich product by pyrolysis in the closed system under a limited quantity of oxygen $^{[10]}$. Studies showed that BC amendments are capable of mounting soil fertility ${ }^{[10,11]}$. Only limited studies have investigated the potential of $\mathrm{BC}$ to mitigate the negative effects of salt stress on plants. Elbashier et al. ${ }^{[1]}$ reported that $\mathrm{BC}$ application could increase the melon fruit yield and quality, as well as water use efficiency (WUE). Digestate (Di) is an organic amendment formed by the anaerobic digestion in biogas plants and is usually used as a fertilizer ${ }^{[12]}$. Di contains a high proportion of ammonium, which is available for plants ${ }^{[13]}$. Moreover, it contains micro-elements needed for plant growth. Di can contribute to soil organic matter $(\mathrm{OM})$ turnover, improving the soil biological and physicochemical characteristics ${ }^{[14]}$. Effective microorganisms (EM) contain lactic acid bacteria, yeasts, photosynthetic bacteria, actinomycetes, and other types of organisms ${ }^{[11,15,16]}$. These microorganisms can secrete beneficial substances such as vitamins and organic acids, thereby creating an environment favorable for plant growth ${ }^{[17]}$. Moreover, they chelate heavy metals and antioxidants when mixed with organic substances $^{[18]}$.

Melon (Cucumis melo L.) is an economically crucial annual plant cultivated all over the world. It is helpful to maintain vision health, strong bones and teeth ${ }^{[19]}$. Melon is a moderately salt-tolerant plant with a threshold of about $1 \mathrm{dS} / \mathrm{m}^{[20]}$. Under saline irrigation, the total yield of melon and watermelon was decreased with the increasing salinity ${ }^{[21]}$. We hypothesized that the combinations of above-mentioned organic amendments would 
be more effective in enhancing soil properties and plant growth under saline irrigation since they take advantage of each amendment's nature. Therefore, this study focused on investigating the effects of the combinations of BC, Di and EM on soil properties, melon growth under saline irrigation. It aims to provide the scientific evidences for organic amendments application as a promising strategy for optimizing saline water use and replacing chemical fertilization in the melon production.

\section{Materials and methods}

\subsection{Experimental site and climatic condition}

The experiments were conducted for two consecutive years (2017-2018) at the Water-Saving Park of Hohai University, Nanjing, China. It is located on latitude $31^{\circ} 57 \mathrm{~N}$ and longitude $118^{\circ} 50^{\prime} \mathrm{E}$. This area is characterized by a humid subtropical climate influenced by the East Asia Monsoon. The annual mean temperature, evaporation and precipitation are $15.5^{\circ} \mathrm{C}, 1472.5 \mathrm{~mm}$ and $1072.9 \mathrm{~mm}$, respectively. The soil used is sandy clayey loam. Table 1 lists the main properties of the experimental soil.

\subsection{Experimental design}

Melon seeds were sown in a nursery on April 20, 2017 and April 23, 2018. They were transplanted to the pots at the four-leaf stage (May 4, 2017; May 6, 2018) and grown in a greenhouse. Figure 1 indicated the shape and dimensions of the pots (each pot is $0.300211 \mathrm{~m}^{3}$ in volume and it contains $10 \mathrm{~kg}$ of soil). The air temperature inside the greenhouse was kept at $(30.5 \pm 2)^{\circ} \mathrm{C}$ during

the growing seasons, while it ranged from $18.5^{\circ} \mathrm{C}$ to $41.0^{\circ} \mathrm{C}$ outside The amount of irrigation was based on the pan evaporation method $^{[11]}$.

Table 1 Properties of the tested soil, BC and Di

\begin{tabular}{lccc}
\hline \multirow{2}{*}{ Parameters } & \multicolumn{3}{c}{ Value } \\
\cline { 2 - 4 } & Soil & BC & Di \\
\hline $\mathrm{EC} / \mathrm{dS} \cdot \mathrm{m}^{-1}$ & $0.20^{1}$ & $2.50^{1}$ & 1.50 \\
$\mathrm{SH}$ & $7.70^{1}$ & $7.50^{1}$ & $7.0-7.5$ \\
$\mathrm{Silt} / \%$ & 33.0 & - & - \\
$\mathrm{Clay} / \%$ & 39.0 & - & - \\
$\mathrm{OM} / \%$ & 28.0 & - & - \\
$\mathrm{CaCO} / \%$ & 1.70 & 24.0 & 0.7 \\
$\mathrm{BD} / \mathrm{g} \cdot \mathrm{cm}^{-3}$ & 1.90 & - & - \\
$\mathrm{Porosity} / \%$ & 1.42 & 0.24 & - \\
$\mathrm{Na} / \mathrm{mmol}^{-1} \mathrm{~L}^{-1}$ & 46.0 & 71.0 & - \\
$\mathrm{K} / \mathrm{mmol} \cdot \mathrm{L}^{-1}$ & $1.00^{1}$ & $21.0^{1}$ & 12.0 \\
$\mathrm{TN} / \mathrm{g} \cdot \mathrm{kg}^{-1}$ & $0.20^{1}$ & $2.30^{1}$ & 2.00 \\
$\mathrm{TP} / \mathrm{g} \cdot \mathrm{kg}^{-1}$ & 1.31 & 14 & $5.1^{2}$ \\
$\mathrm{TK} / \mathrm{g} \cdot \mathrm{kg}^{-1}$ & 0.90 & 21 & $4.2^{2}$ \\
$\mathrm{Amino} \mathrm{acids} / \%$ & 19.0 & 17 & $3.5^{2}$ \\
$\mathrm{Protein} / \%$ & - & - & $>15.0$ \\
\hline $\mathrm{NWater}$ & - & - & $>2.50$ \\
\hline
\end{tabular}
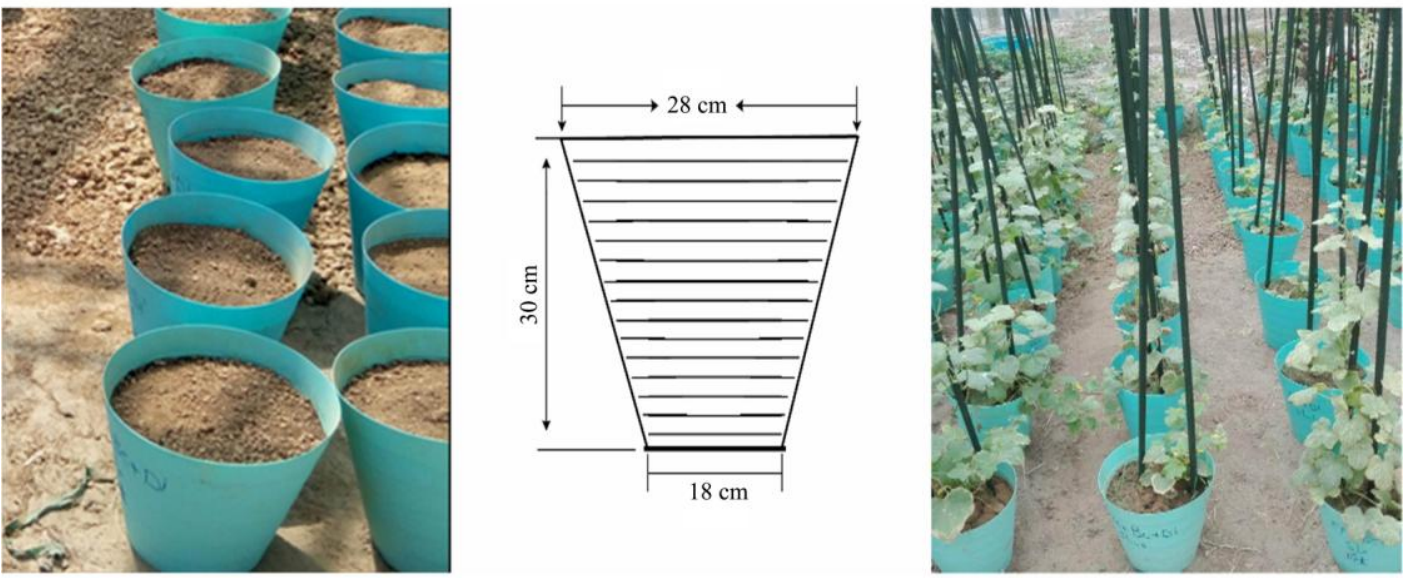

Figure 1 Experimental pots used for melon growth

Two levels of water salinity (SL0 $=0.25 \mathrm{dS} / \mathrm{m}$ and SL1 $=2$ $\mathrm{dS} / \mathrm{m}$ ) were used for irrigation. EM-bokashi, BC and Di were selected as organic amendments. For NPK treatment, the dose of $120-150-150 \mathrm{~kg} / \mathrm{hm}^{2}$ was recommended by adding mineral NPK fertilizer. The double factors randomized design was adopted and two irrigation treatments (SL0, SL1) together with six fertilization treatments $(\mathrm{CK}, \mathrm{NPK}, \mathrm{EM}+\mathrm{BC}, \mathrm{EM}+\mathrm{Di}, \mathrm{BC}+\mathrm{Di}, \mathrm{EM}+\mathrm{BC}+\mathrm{Di})$ were designed as shown in Table 2. Each treatment was performed in three parallel replicates.

EM-bokashi used was provided by Guangzhou Yubang Technology Co., Ltd, China (Record No. QB/44010072158-2013). It had an EC value of $2 \mathrm{dS} / \mathrm{m}$ and $\mathrm{pH}$ of about 5.6. EM-bokashi was added thrice (5 g/pot in each time): 1) $12 \mathrm{~d}$ after melon transplanting, 2) $14 \mathrm{~d}$ after the first dose, and 3) $29 \mathrm{~d}$ after the second dose.

The BC used was produced from pinewood, pyrolyzed at $350^{\circ} \mathrm{C}-550^{\circ} \mathrm{C}$. It was provided by Shandong Tairan Biological Engineering Co., Ltd, China. 5\% of BC (500 g/pot) was thoroughly mixed with soil as the basal fertilization.
Table 2 Experimental treatments

\begin{tabular}{|c|c|}
\hline Irrigation treatments & Descriptions \\
\hline SL0 & $0.25 \mathrm{dS} \cdot \mathrm{m}^{-1}$, tap water, normal irrigation water \\
\hline SL1 & $2 \mathrm{dS} \cdot \mathrm{m}^{-1}, 1 \mathrm{~g} \mathrm{NaCl} \cdot \mathrm{L}^{-1}$, saline irrigation water \\
\hline Fertilization treatments & Descriptions \\
\hline CK & Control, no additions \\
\hline NPK & NPK fertilizer (533-667-667 mg per pot) \\
\hline $\mathrm{EM}+\mathrm{BC}$ & EM-bokashi (5 g per pot, thrice) and BC $5 \%$ (500 g/pot) \\
\hline $\mathrm{EM}+\mathrm{Di}$ & $\begin{array}{l}\text { EM-bokashi ( } 5 \mathrm{~g} \text { per pot, thrice) and } \mathrm{Di}(500 \mathrm{~mL} \text { per pot, } \\
\text { twice) }\end{array}$ \\
\hline $\mathrm{BC}+\mathrm{Di}$ & BC $5 \%$ (500 g per pot) and $\mathrm{Di}(500 \mathrm{~mL}$ per pot, twice) \\
\hline $\mathrm{EM}+\mathrm{BC}+\mathrm{Di}$ & $\begin{array}{l}\text { EM-bokashi ( } 5 \mathrm{~g} \text { per pot, thrice) with BC } 5 \% \text { ( } 500 \mathrm{~g} \text { per } \\
\text { pot) and Di ( } 500 \mathrm{~mL} \text { per pot, twice) }\end{array}$ \\
\hline
\end{tabular}

The Di used was produced by the anaerobic digestion of cow and rabbit manure in the mesophilic $\left(20^{\circ} \mathrm{C}-40^{\circ} \mathrm{C}\right)$ condition. It was provided by the Farmhouse Small Manor Company, Jining, Shandong, China. Di was applied twice $(500 \mathrm{~mL} /$ pot each time $)$ : 1) $12 \mathrm{~d}$ after melon transplanting, 2) one month after the first 
dose. The properties of $\mathrm{BC}$ and $\mathrm{Di}$ are listed in Table 1.

After three months, melon plants were harvested and soil samples were collected to determine the physicochemical properties. Moreover, parameters of photosynthetic rate (Pr), plant leave sodium $\left(\mathrm{Na}^{+}\right)$content, melon fruit yield and WUE were measured for the different treatments.

\subsection{Soil and organic amendment parameters determination}

\subsubsection{Soil $\mathrm{pH}$ and $\mathrm{OM}$}

The $\mathrm{pH}$ (1:5 soil: water ratio, w/v) was determined using $\mathrm{pH}$ meter model 3510. OM was determined by titration with ferrous ammonium sulphate solution according to Page et $\mathrm{al}^{[22]}$.

2.3.2 Sodium adsorptive capacity (SAC) of organic amendments

It was carried out in the laboratory at $25^{\circ} \mathrm{C}$. Four combinations of organic amendments were stimulated and among them $0.02 \mathrm{~g}$ of EM-Bokashi, $2.1 \mathrm{~g}$ of $\mathrm{BC}$ and $2.1 \mathrm{~mL}$ of Di were transferred into $50 \mathrm{~mL}$ polypropylene tubes containing $40 \mathrm{~mL}$ of $0.25 \mathrm{dS} / \mathrm{m}$ and $2 \mathrm{dS} / \mathrm{m} \mathrm{NaCl}$ solution with three replicates for each treatment. The tubes were shaken manually for $5 \mathrm{~min}$ then agitated for $24 \mathrm{~h}$ on a shaker at $45 \mathrm{r} / \mathrm{min}$. After shaking, the supernatant was separated by centrifugation at $155 \mathrm{~g}$ (RCF) for 5 min. A clear aliquot was used for $\mathrm{Na}^{+}$analysis by flame photometer, as reported by Estefan et al. ${ }^{[23]}$. The SAC of these organic amendments was calculated by using equation $1^{[24]}$.

$$
S A C=\frac{\left(c_{i}-c_{f}\right)}{m} \times V
$$

where, $C_{i}$ and $C_{f}$ are the initial and final concentrations of $\mathrm{Na}^{+}$ before and after amendments addition, $\mathrm{mg} / \mathrm{L} ; V$ is volume of $\mathrm{NaCl}$ solution, $\mathrm{mL} ; m$ is the dosage of amendments, $\mathrm{g}$.

2.3.3 Field capacity (FC), permanent wilting point (PWP) and available water capacity (AWC) of soil

FC and PWP were determined at 0.33 and 15.0 bar (matrix potentials), respectively, using pressure plate apparatus. The AWC was determined as follows ${ }^{[25]}$ :

$$
A W C=F C-\theta_{P W P}
$$

where, $\theta_{P W P}$ is the water content at the PWP and FC is the field capacity.

\subsection{Plant parameters determination}

2.4.1 Pr

At the fruit stage, melon leaves in the upper canopy of each treatment were selected for Pr determination. It was measured during the period of 09:00 a.m.-12:00 p.m. using a portable photosynthesis system (TPS-2, Cambridge, UK).

\subsection{2 $\mathrm{Na}^{+}$content in melon leaves}

It was measured at harvesting stage based on the method described by Estefan et al ${ }^{[23]}$.

2.4.3 Melon fruit yield and WUE

Melon fruit yield was determined according to Graber et al. ${ }^{[26]}$. WUE for each treatment was calculated using the following equation:

$$
W U E=\frac{\text { Crop yield }(\mathrm{kg})}{\text { Total water used }\left(\mathrm{m}^{3}\right)}
$$

\subsection{Statistical test}

The experimental data were analyzed using the Minitab® 18.1 software. Two-way analysis of variance (ANOVA) was used in these tests and the separation of means of the treatments was done with a Duncan's test. For all statistical tests, results were considered significant when $p<0.05$. And the least significant difference (LSD) was used to put up multiple comparisons. The GraphPad Prism 6 software package was adopted to generate the graphs based on the experimental results.

\section{Results}

3.1 Effects of organic amendments on soil parameters and SAC 3.1.1 $\mathrm{pH}$ and $\mathrm{OM}$

From Table 3, it could be seen that the organic amendments decreased the soil $\mathrm{pH}$ under both SL0 and SL1 in comparison to $\mathrm{CK}$ in 2017. The lower $\mathrm{pH}$ values were noticed with $\mathrm{EM}+\mathrm{BC}+\mathrm{Di}$, meanwhile, no significant differences were found between SLO and SL1. Unlike first season (2017), the results obtained in 2018 showed that the organic amendments increased the soil $\mathrm{pH}$ significantly $(p<0.05)$ compared to CK and NPK. The higher $\mathrm{pH}$ values were obtained by $\mathrm{EM}+\mathrm{Di}$, followed by $\mathrm{EM}+\mathrm{BC}+\mathrm{Di}$, while the lowest values were noticed with CK under SL0 and NPK under SL1. No significant differences were found across EM+Di,

\begin{tabular}{|c|c|c|c|c|c|}
\hline \multirow{2}{*}{ Treatments } & \multirow{2}{*}{$\begin{array}{l}\text { Saline } \\
\text { water }\end{array}$} & \multicolumn{2}{|c|}{$\mathrm{pH}(1: 5)$} & \multicolumn{2}{|c|}{$\mathrm{OM}(\%)$} \\
\hline & & 2017 & 2018 & 2017 & 2018 \\
\hline CK & \multirow{6}{*}{ SLO } & $7.61^{\mathrm{Aa}}$ & $7.5^{\mathrm{Af}}$ & $1.8^{\mathrm{Ae}}$ & $1.7^{\mathrm{Ae}}$ \\
\hline NPK & & $7.32^{\text {Aabc }}$ & $7.9^{\text {Ade }}$ & $1.7^{\mathrm{Ae}}$ & $1.7^{\mathrm{Ae}}$ \\
\hline $\mathrm{EM}+\mathrm{BC}$ & & $7.29^{\text {Aabc }}$ & $8.3^{\mathrm{Abcd}}$ & $2.0^{\mathrm{Ae}}$ & $2.7^{\mathrm{Ad}}$ \\
\hline $\mathrm{EM}+\mathrm{Di}$ & & $7.54^{\mathrm{Aab}}$ & $8.8^{\mathrm{Aa}}$ & $3.5^{\mathrm{Ac}}$ & $3.4^{\mathrm{Ac}}$ \\
\hline $\mathrm{BC}+\mathrm{Di}$ & & $7.17^{\mathrm{Abcd}}$ & $8.5^{\text {Aabc }}$ & $4.1^{\mathrm{Abc}}$ & $4.3^{\mathrm{Ab}}$ \\
\hline $\mathrm{EM}+\mathrm{BC}+\mathrm{Di}$ & & $7.02^{\text {Acd }}$ & $8.7^{\text {Aab }}$ & $5.3^{\mathrm{Aa}}$ & $5.5^{\mathrm{Aa}}$ \\
\hline CK & \multirow{6}{*}{ SL1 } & $7.72^{\mathrm{Aa}}$ & $8.1^{\text {Acde }}$ & $1.8^{\mathrm{Ae}}$ & $1.0^{\mathrm{Bd}}$ \\
\hline NPK & & $6.84^{\mathrm{Ad}}$ & $7.9^{\text {Aed }}$ & $1.8^{\mathrm{Ae}}$ & $1.1^{\mathrm{Bd}}$ \\
\hline $\mathrm{EM}+\mathrm{BC}$ & & $7.21^{\mathrm{Abc}}$ & $8.4^{\mathrm{Abc}}$ & $2.8^{\mathrm{Ad}}$ & $3.0^{\mathrm{Bc}}$ \\
\hline $\mathrm{EM}+\mathrm{Di}$ & & $7.36^{\mathrm{Aabc}}$ & $8.7^{\text {Aab }}$ & $3.8^{\mathrm{Abc}}$ & $2.9^{\mathrm{Bc}}$ \\
\hline $\mathrm{BC}+\mathrm{Di}$ & & $7.16^{\mathrm{Abcd}}$ & $8.5^{\text {Aabc }}$ & $4.2^{\mathrm{Ab}}$ & $4.0^{\mathrm{Bb}}$ \\
\hline $\mathrm{EM}+\mathrm{BC}+\mathrm{Di}$ & & $6.83^{\mathrm{Ad}}$ & $8.6^{\text {Aab }}$ & $5.2^{\mathrm{Aa}}$ & $4.9^{\mathrm{Ba}}$ \\
\hline
\end{tabular}
$\mathrm{BC}+\mathrm{Di}$ and $\mathrm{EM}+\mathrm{BC}+\mathrm{Di}$, as seen in Table 3 .

Table 3 Soil pH and OM

Note: Means are significantly different when followed by the different letters between irrigations (uppercase) or among amendments (lowercase) $(p<0.05)$.

Generally, application of organic amendments could obviously $(p<0.05)$ increase soil OM compared with CK and NPK (Table 3). In 2017 and 2018, $\mathrm{EM}+\mathrm{BC}+\mathrm{Di}$ showed highest $\mathrm{OM}$ values compared to other treatments. $\mathrm{BC}+\mathrm{Di}$ was more effective in enhancing soil $\mathrm{OM}$ than $\mathrm{EM}+\mathrm{BC}$ and $\mathrm{EM}+\mathrm{Di}$. The lower values were obtained by CK and NPK.

3.1.2 SAC

As shown in Figure 2, the higher SAC of organic amendments was detected at $2 \mathrm{dS} / \mathrm{m}$ of $\mathrm{NaCl}$ solution. The highest $\mathrm{SAC}$ was recorded by $\mathrm{EM}+\mathrm{BC}(49.3 \mathrm{mg} / \mathrm{g})$ followed by $\mathrm{BC}+\mathrm{Di}(46.5 \mathrm{mg} / \mathrm{g})$. EM+ Di had no effect on the SAC.

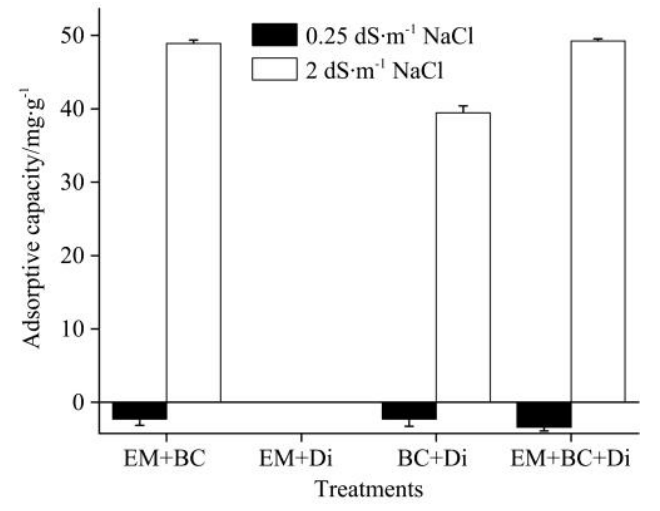

Figure 2 SAC of organic amendments under SL0 and SL1

\subsubsection{FC, PWP and AWC}

As shown in Table 4, organic amendments significantly $(p<0.05)$ increased soil FC compared to CK and NPK. Meanwhile, saline irrigation resulted in decreasing soil FC and this 
decrement became significant $(p<0.05)$ in 2018. In 2017, the higher soil FC values were noticed with $\mathrm{EM}+\mathrm{BC}+\mathrm{Di}(40 \%$ and $38.8 \%$ for SL0 and SL1) and EM+BC (38.2\% for SL0). While in 2018, the higher soil FC values were also obtained by $\mathrm{EM}+\mathrm{BC}+\mathrm{Di}$ and EM+BC. Organic amendments significantly $(p<0.05)$ increased PWP compared to CK and NPK (Table 4). EM+BC+Di showed higher PWP both in 2017 and 2018. SL1 had no significant differences in PWP with SL0. Under SL1, there were no significant differences between $\mathrm{EM}+\mathrm{BC}+\mathrm{Di}$ and the remaining combinations. SL1 significantly $(p<0.05)$ decreased AWC compared to SL0. In 2017, the higher AWC values were recorded by $\mathrm{EM}+\mathrm{BC}+\mathrm{Di}$, followed by $\mathrm{EM}+\mathrm{BC}$ and $\mathrm{EM}+\mathrm{Di}$. While, in 2018, no significant differences in AWC were observed across all the amendment combinations under SL1.

Table 4 Soil FC, PWP and AWC (\%)

\begin{tabular}{|c|c|c|c|c|c|c|c|}
\hline \multirow{2}{*}{ Treatments } & \multirow{2}{*}{ Saline water } & \multicolumn{2}{|c|}{$\mathrm{FC}$} & \multicolumn{2}{|c|}{ PWP } & \multicolumn{2}{|c|}{ AWC } \\
\hline & & 2017 & 2018 & 2017 & 2018 & 2017 & 2018 \\
\hline CK & \multirow{6}{*}{ SL0 } & $32.0^{\mathrm{Acd}}$ & $32.0^{\mathrm{Ac}}$ & $16.3^{\text {Ade }}$ & $16.4^{\text {Acd }}$ & $15.7^{\text {Acde }}$ & $15.6^{\mathrm{Ac}}$ \\
\hline NPK & & $31.9^{\text {Acd }}$ & $32.6^{\mathrm{Ac}}$ & $16.7^{\text {Acde }}$ & $16.6^{\text {Acd }}$ & $15.2^{\text {Ade }}$ & $16.0^{\mathrm{Ac}}$ \\
\hline $\mathrm{EM}+\mathrm{BC}$ & & $38.2^{\text {Aab }}$ & $39.0^{\text {Aab }}$ & $18.0^{\mathrm{Aab}}$ & $18.5^{\mathrm{Aab}}$ & $20.2^{\mathrm{Aab}}$ & $20.5^{\mathrm{Aa}}$ \\
\hline EM+Di & & $35.4^{\mathrm{Abc}}$ & $36.3^{\mathrm{Ab}}$ & $17.9^{\mathrm{Aabc}}$ & $18.5^{\mathrm{Aab}}$ & $17.5^{\mathrm{Abcd}}$ & $17.8^{\mathrm{Abc}}$ \\
\hline $\mathrm{BC}+\mathrm{Di}$ & & $35.8^{\mathrm{Abc}}$ & $36.6^{\mathrm{Ab}}$ & $17.3^{\mathrm{Abcd}}$ & $17.4^{\text {Aabcd }}$ & $18.5^{\mathrm{Aabc}}$ & $19.2^{\text {Aab }}$ \\
\hline $\mathrm{EM}+\mathrm{BC}+\mathrm{Di}$ & & $40.0^{\mathrm{Aa}}$ & $41.0^{\mathrm{Aa}}$ & $18.9^{\mathrm{Aa}}$ & $19.4^{\mathrm{Aa}}$ & $21.1^{\mathrm{Aa}}$ & $21.6^{\mathrm{Aa}}$ \\
\hline CK & \multirow{5}{*}{ SL1 } & $30.0^{\mathrm{Ad}}$ & $30.1^{\mathrm{Bc}}$ & $15.8^{\mathrm{Ae}}$ & $15.6^{\mathrm{Ad}}$ & $14.2^{\mathrm{Ae}}$ & $14.4^{\mathrm{Bb}}$ \\
\hline NPK & & $30.0^{\mathrm{Ad}}$ & $30.0^{\mathrm{Bc}}$ & $15.9^{\mathrm{Ae}}$ & $15.1^{\mathrm{Ad}}$ & $14.1^{\mathrm{Ae}}$ & $14.9^{\mathrm{Bb}}$ \\
\hline $\mathrm{EM}+\mathrm{BC}$ & & $37.0^{\mathrm{Aab}}$ & $38.0^{\mathrm{Bab}}$ & $17.9^{\mathrm{Aabc}}$ & $18.3^{\text {Aabc }}$ & $19.1^{\mathrm{Aab}}$ & $19.7^{\mathrm{Ba}}$ \\
\hline $\mathrm{EM}+\mathrm{Di}$ & & $37.6^{\text {Aab }}$ & $37.2^{\mathrm{Bab}}$ & $18.0^{\text {Aab }}$ & $18.2^{\text {Aabc }}$ & $19.6^{\text {Aab }}$ & $19.0^{\mathrm{Ba}}$ \\
\hline $\mathrm{EM}+\mathrm{BC}+\mathrm{Di}$ & & $38.8^{\text {Aab }}$ & $40.2^{\mathrm{Ba}}$ & $18.8^{\mathrm{Aa}}$ & $19.3^{\mathrm{Aa}}$ & $21.0^{\mathrm{Aa}}$ & $20.9^{\mathrm{Ba}}$ \\
\hline
\end{tabular}

Note: Means are significantly different when followed by the different letters between irrigations (uppercase) or among amendments (lowercase) ( $p<0.05)$.

\subsection{Effects of organic amendments on plant parameters} 3.2.1 Pr

SL1 significantly $(p<0.05)$ decreased the $\operatorname{Pr}$ at the fruit stage compared to SL0 (Figure 3). EM+BC+Di recorded the maximum

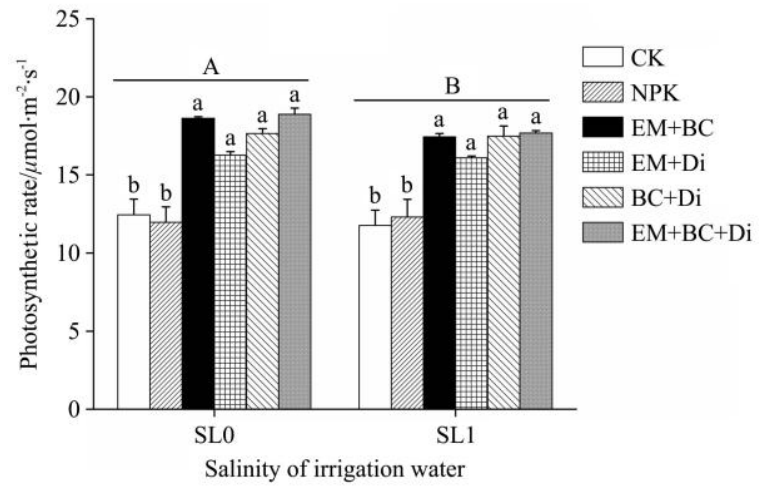

a. 2017
Pr, while no significant differences were observed among organic amendment combinations under irrigation treatments except under SL1 in 2018. However, organic amendments showed higher Pr values $(p<0.05)$ than CK and NPK.

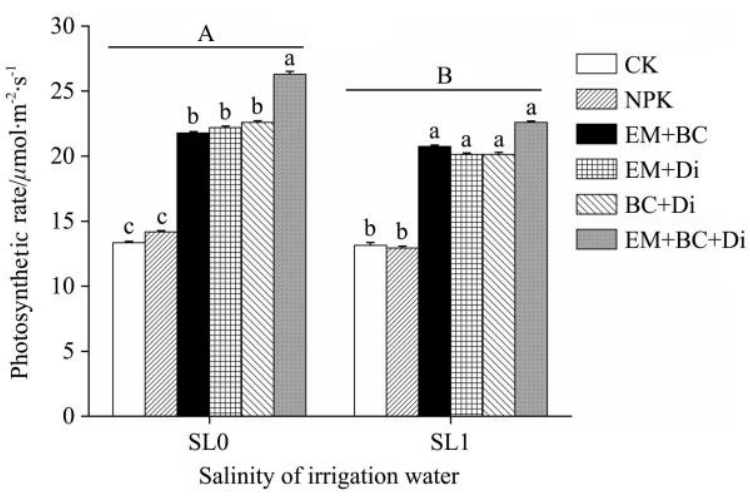

b. 2018

Note: Means are significantly different when followed by the different letters between irrigations (uppercase) or among amendments (lowercase) ( $p<0.05$ )

Figure $3 \mathrm{Pr}$ at the fruit stage

\subsection{2 $\mathrm{Na}^{+}$content in melon leaves}

Figure 4 showed saline irrigation had a significant $(p<0.05)$ effect on $\mathrm{Na}^{+}$content in melon leaves. The $\mathrm{Na}^{+}$content tended to increase with the increasing of salts in irrigation water. However, $\mathrm{EM}+\mathrm{BC}+\mathrm{Di}$ significantly $(p<0.05)$ decreased the $\mathrm{Na}^{+}$content in melon leaves compared to CK and NPK. In 2017, the higher $\mathrm{Na}^{+}$ values were obtained by $\mathrm{CK}$, followed by NPK. Whereas, the lower $\mathrm{Na}^{+}$values were noticed with $\mathrm{BC}+\mathrm{Di}$ and $\mathrm{EM}+\mathrm{BC}+\mathrm{Di}$ under SL0. EM+Di, EM+BC and EM+BC+Di showed lower $\mathrm{Na}^{+}$ values under SL1. In 2018, the higher $\mathrm{Na}^{+}$content was recorded by BC+Di, followed by CK under SL0. Under SL1, the CK and NPK had higher $\mathrm{Na}^{+}$contents compared to other amendment treatments (Figure 4).

\subsubsection{Melon fruit yield and WUE}

Figure 5 showed saline irrigation led to a significant $(p<0.05)$ decrease in melon fruit yield. In 2017, EM+BC+Di showed a higher $(p<0.05)$ yield compared to other treatments under SLO. While under SL1, the maximum yields were observed with $\mathrm{EM}+\mathrm{BC}+\mathrm{Di}$ and $\mathrm{EM}+\mathrm{BC}$. In 2018, under SL0, the higher $(p<0.05)$ yield was recorded by $\mathrm{EM}+\mathrm{BC}+\mathrm{Di}$ compared to the remaining treatments, while they were obtained by $\mathrm{EM}+\mathrm{BC}+\mathrm{Di}$ and $\mathrm{EM}+\mathrm{BC}$ for SL1. Overall, $\mathrm{EM}+\mathrm{BC}+\mathrm{Di}$ significantly $(p<0.05)$ increased yields compared to CK and NPK (Figure 5).

From Figure 6, it could be seen SL1 significantly $(p<0.05)$ decreased WUE. However, EM+BC+Di significantly enhanced WUE under both SL0 and SL1 when compared to CK and NPK. In 2017, EM+BC+Di showed a higher $(p<0.05)$ WUE compared to the remaining treatments under SL0. While under SL1, the WUE values had unsignificant differences among the organic amendment combinations. In 2018, the higher WUE was observed with $\mathrm{EM}+\mathrm{BC}+\mathrm{Di}$ compared to other treatments under SL0, while for $\mathrm{SL1}$, the higher WUE was obtained by $\mathrm{EM}+\mathrm{BC}+\mathrm{Di}$ and $\mathrm{EM}+\mathrm{BC}$. 

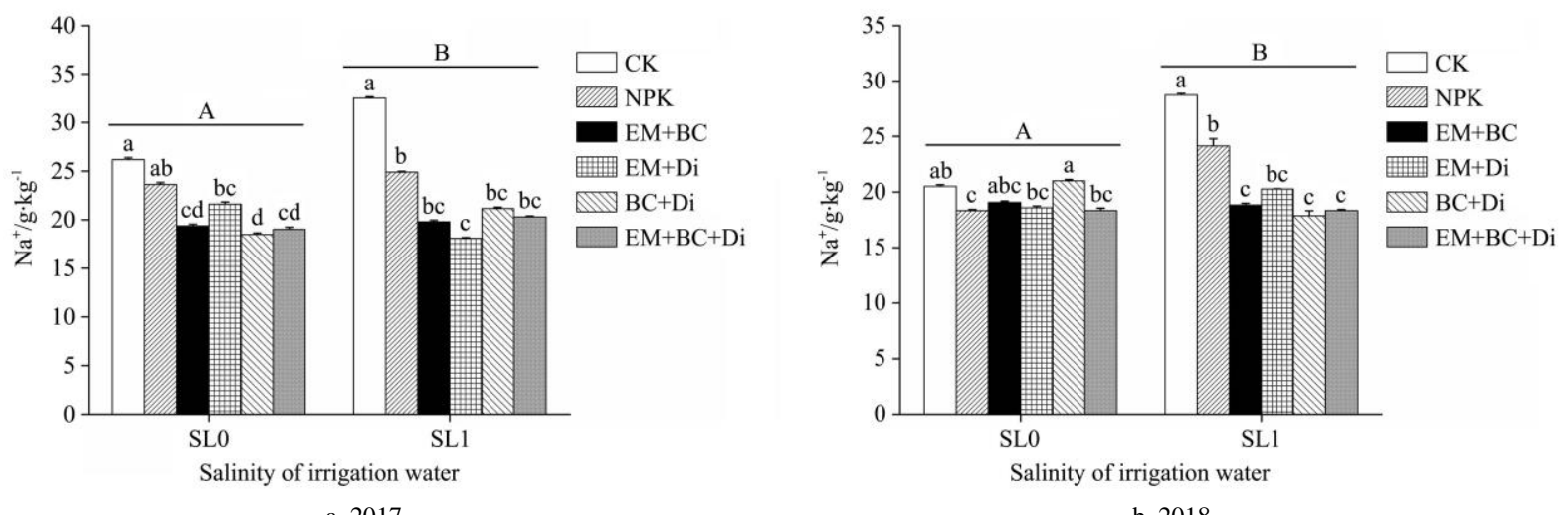

Note: Means are significantly different when followed by the different letters between irrigations (uppercase) or among amendments $($ lowercase) $(p<0.05)$

Figure $4 \mathrm{Na}^{+}$content in leaves
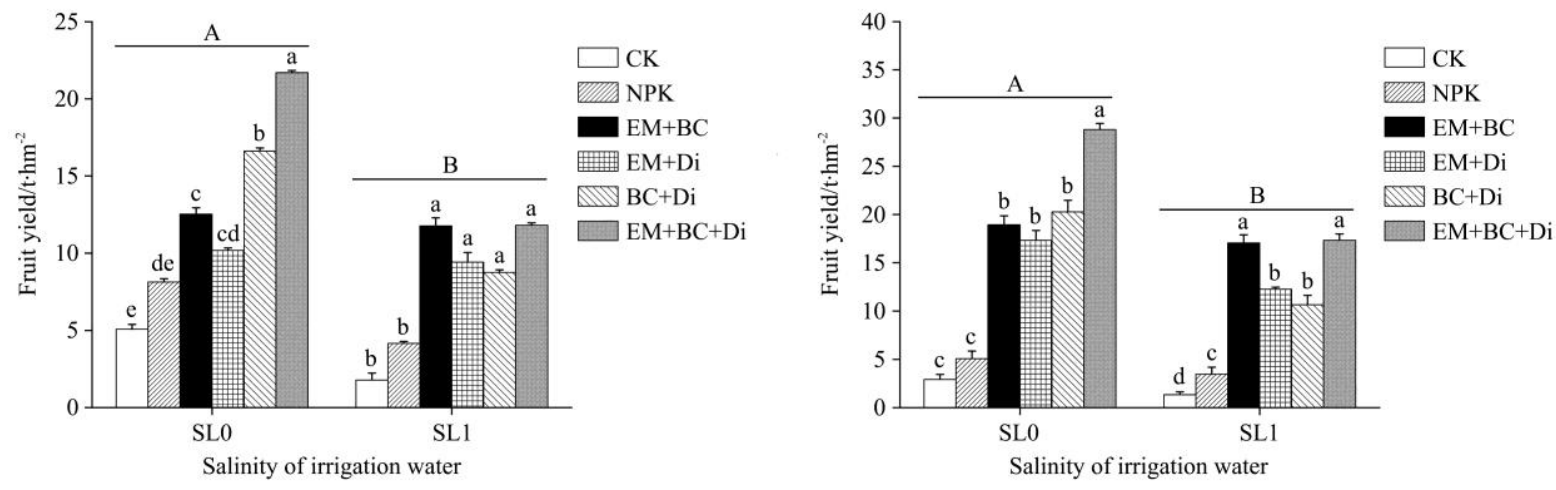

a. 2017

b. 2018

Note: Means are significantly different when followed by the different letters between irrigations (uppercase) or among amendments (lowercase) $(p<0.05)$

Figure 5 Melon fruit yield

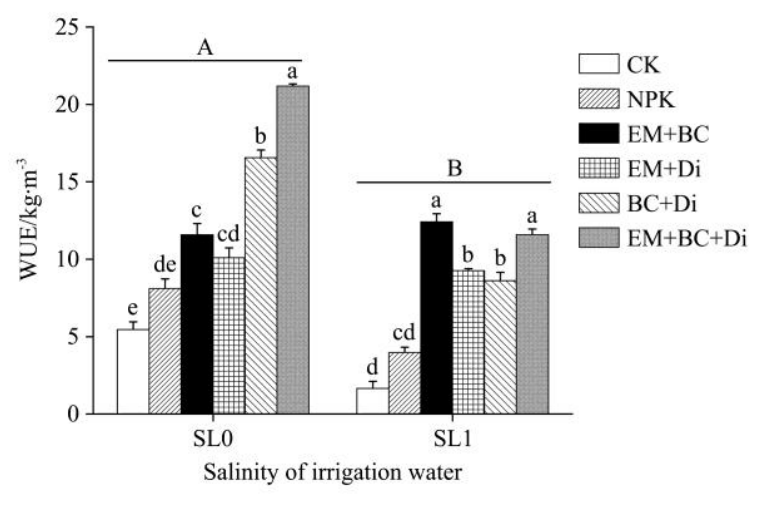

a. 2017

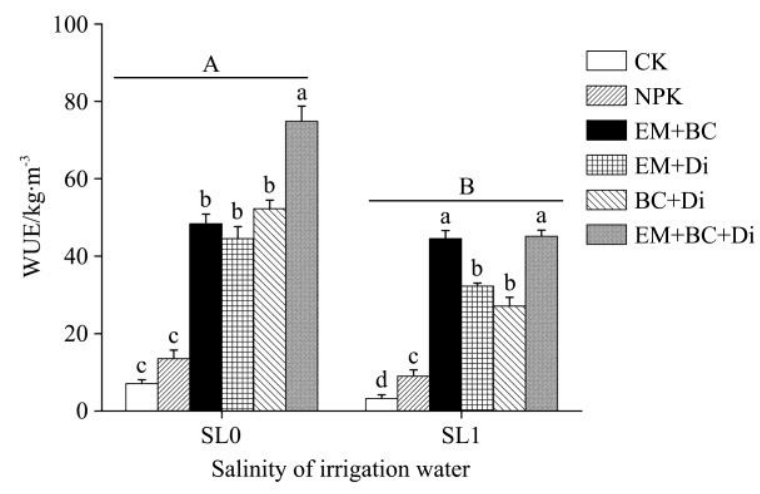

b. 2018

Note: Means are significantly different when followed by the different letters between irrigations (uppercase) or among amendments (lowercase) $(p<0.05)$

Figure 6 WUE

\section{Discussion}

4.1 Effects of organic amendments on soil parameters and SAC under saline irrigation

Saline irrigation reduces the yield and quality of crops, since it might lead to secondary soil salinization ${ }^{[27]}$. However, moderately saline water can be utilized for irrigation when proper strategies are applied $^{[28,29]}$. In this study, saline irrigation had no significant effect on soil $\mathrm{pH}$ at yearly scale. Meanwhile, the season of 2018 showed higher $\mathrm{pH}$ values compared to 2017. Generally, saline irrigation increased the $\mathrm{pH}$ of soils $^{[30]}$. Using saline water increased the $\mathrm{Na}^{+}$values, this increase might become significant in 2018 , so the time factor played an important role in increasing soil $\mathrm{Na}^{+[14]}$. Unlike 2017, there was a significant increase in soil $\mathrm{pH}$ under EM, BC and Di treatments in 2018. In fact, the $\mathrm{pH}$ rise following organic amendment additions was due to the increases in alkaline cations. It was reported that $\mathrm{BC}$ increases soil $\mathrm{pH}$ of 0.6-1.0 units on average due to its alkaline nature ${ }^{[11,14]}$. The addition of $\mathrm{Di}$ to soils often yields an increase in $\mathrm{pH}^{[12,14,29]}$. Therefore, this $\mathrm{pH}$ rise in 2018 could be attributed to the increases in alkaline cations following EM, BC and Di additions on one hand, the decrease of soil $\mathrm{Na}^{+}$uptake by melon on the other hand, as also reported by Bachmann et al. ${ }^{[31]}$.

$\mathrm{EM}+\mathrm{BC}+\mathrm{Di}$ showed the highest $\mathrm{OM}$ values compared to other treatments under both SL0 and SL1. In 2017, it increased the OM by about $66 \%$ and $65 \%$ under SLO and SL1 respectively compared to CK. While, in 2018, soil OM was increased about $69 \%$ and $80 \%$. Moreover, $\mathrm{BC}+\mathrm{Di}$ was more effective in enhancing soil $\mathrm{OM}$ than $\mathrm{EM}+\mathrm{BC}$ and $\mathrm{EM}+\mathrm{Di}$. It is because that they contain high soluble organic substances ${ }^{[29]}$. 
In this study, there was no SAC action under EM+Di treatment. While it was recorded higher values under $2 \mathrm{dS} / \mathrm{m} \mathrm{NaCl}$ solution with $\mathrm{EM}+\mathrm{BC}, \mathrm{BC}+\mathrm{Di}$ and $\mathrm{EM}+\mathrm{BC}+\mathrm{Di}$. Akhtar et al. ${ }^{[24]}$ also reported that the $\mathrm{BC}$ application under salt stress increased $\mathrm{K}^{+}$and decreased $\mathrm{Na}^{+}$. $\mathrm{EM}$ manure could increase the exchange of $\mathrm{Ca}^{2+}$ with $\mathrm{Na}^{+}$, and consequently, decreased the exchangeable $\mathrm{Na}^{+}$in the solution $^{[18,32]}$. It can interpret why melon growth is improved by use of these amendments under saline irrigation.

The organic amendments evidently increased FC, PWP and AWC under SL1 and SL0. Saline irrigation significantly decreased FC and AWC particularly in 2018, while it had no significant effect on PWP. She et al. ${ }^{[32]}$ found that salt stress reduced soil productivity due to the lower PWP, FC and AWC of the soil under saline irrigation. $\mathrm{EM}+\mathrm{BC}+\mathrm{Di}$ exhibited higher AWC values under SL1 and SLO. Many factors such as aggregation, soil OM content and soil texture can affect AWC ${ }^{[31]}$. Głąb et al. ${ }^{[33]}$ proved BC application increased AWC in clayey soil, especially for sandy soil. Herath et al. ${ }^{[34]}$ obtained similar results in a silt loam soil. Głodowska et al. ${ }^{[35]}$ reported that organic amendments could improve water holding capacity in the soil. These findings supported that organic amendment combinations could enhance soil water availability under saline irrigation.

\subsection{Effects of organic amendments on $\mathrm{Pr}$ and $\mathrm{Na}^{+}$in melon} leaves

The salt stress hinders plant photosynthesis due to reductions in osmosis and increases in ion toxicity ${ }^{[1]}$. We found that saline irrigation significantly reduced the Pr of melon leaves. However, it showed that amending the soil with EM, BC and Di enhanced the Pr under saline irrigation. The same findings were obtained by Głodowska et al. ${ }^{[35]}$, who found that $\mathrm{BC}$ played a significant role in mitigating salt stress in plants by capturing transient $\mathrm{Na}^{+}$, while releasing $\mathrm{K}^{+}, \mathrm{Ca}^{2+}$ and $\mathrm{Mg}^{2+}$ from $\mathrm{BC}$ into the soil solution. In addition, EM and Di can reduce the soil salt stress due to promotion of soil enzyme activity, release of organic acids and adsorption of $\mathrm{Na}^{+[36]}$. Therefore, the combination of EM, BC and Di had beneficial effects for melon growth, thus increasing the Pr.

Saline irrigation increased $\mathrm{Na}^{+}$content in melon leaves compared to the normal irrigation ${ }^{[32]}$. Application of EM, BC and Di significantly decreased $\mathrm{Na}^{+}$content in leaves compared to $\mathrm{CK}$ and NPK. This may be attributed to the increased SAC of EM, $\mathrm{BC}$ and Di under saline irrigation (Figure 2), which hinders the $\mathrm{Na}^{+}$ uptake by melon. The same findings were reported that organic amendments played active roles in mitigating salt stress in plants by capturing soluble $\mathrm{Na}^{+}$in soil solution ${ }^{[35,36]}$.

\subsection{Effects of organic amendments on melon fruit yield and WUE}

The results in this study demonstrated that the melon fruit yield was decreased under saline irrigation. Similar results were obtained by Colla et al. ${ }^{[37]}$ who found that melon plants growing under greenhouse were significantly affected by both the salinity of irrigation water and the time of exposure to salt. Also, they mentioned that vegetative growth and fruit yield were significantly reduced by salt stress. Organic amendments have the available plant nutrients and retain more water, therefore, application of EM, $\mathrm{BC}$ and Di could significantly increase the yield ${ }^{[1-14,38]}$. $\mathrm{EM}+\mathrm{BC}+\mathrm{Di}$ was found to be the most effective in enhancing melon fruit yield because it takes advantage of combining them in one amendment to keep nutrients balance.

WUE was reduced by saline irrigation ${ }^{[39]}$. Khataar et al. ${ }^{[40]}$ reported that $\mathrm{Na}^{+}$toxicity, ion balance disorder and reduced uptake of water and nutrients were the key reasons for bean and wheat yield reduction under salt stress. Our results indicated that $\mathrm{EM}+\mathrm{BC}+\mathrm{Di}$ could significantly increase the WUE due to soil improvement. Uzoma et al. ${ }^{[41]}$ reported higher WUE of the crop that received organic inputs was positively correlated to improved soil properties. Elbashier et al. ${ }^{[11,14]}$ set EM, BC and Di individually as a treatment and proved they could enhance $\mathrm{pH}, \mathrm{OM}$ and water availability of soil, increase WUE and melon fruit yield under saline irrigation compared with the CK and NPK. In this study, EM, BC and Di were combined as fertilization treatments, it revealed that $\mathrm{EM}+\mathrm{BC}+\mathrm{Di}$ exhibited the best effects on soil improvement and melon fruit yield over two seasons. $\mathrm{EM}+\mathrm{BC}+\mathrm{Di}$ at the experimental doses and frequencies could be recommended for melon production as an alternative for mineral NPK fertilizer application under saline irrigation. Further studies are necessary to evaluate the economic feasibility of these organic amendments at field scale, thus making the strategy more reliable.

\section{Conclusions}

In this study, it demonstrated the saline irrigation reduces soil water availability and causes a decrease in melon growth and fruit yield. Combined application of EM, BC and Di could enhance soil OM, SAC and soil water availability, reduce $\mathrm{Na}^{+}$content in melon leaves, increase Pr, WUE and melon fruit yield under saline irrigation. Furthermore, EM+BC+Di exhibited the most effective effects on the soil improvement, melon growth, WUE and fruit yield increase compared with NPK and combinations of two organic amendments. Organic amendments to mitigate the negative effects of saline irrigation indicated a positive interaction among these amendments with soil water, nutrients and salts. It proved that $\mathrm{EM}+\mathrm{BC}+\mathrm{Di}$ had a positive effect on the soil improvement as well as melon fruit yield, and it can be used as an alternative strategy for mineral NPK fertilization of melon under saline irrigation at application rates and frequencies of EM-bokashi (5 g/pot, thrice), BC (500 g/pot, once), and Di (500 mL/pot, twice). Further studies are needed to evaluate the economic feasibility under different application doses and frequencies of these organic amendments at field scale.

\section{Acknowledgements}

This research was funded by the National Nature Science Foundation of China (51779182), the Fundamental Research Funds for the Central Universities (2017B20414), the National Key Research and Development Program (2020YFD0900705) and the Science and Technology Project for Nanjing Water Conservancy Bureau (2019-208-6). The authors would like to acknowledge the University of Melbourne for the technical platform.

\section{[References]}

[1] Machado R, Serralheiro R. Soil salinity: effect on vegetable crop growth Management practices to prevent and mitigate soil salinization. Horticulturae, 2017; 3(2): 30-42.

[2] Jouyban E R, Zeinolabedin E, Valdiani A. The effects of salt stress on plant growth. Technical Journal of Engineering and Applied Sciences, 2012; 2(1): 7-10.

[3] Li C, Lei J, Zhao Y, Xu X, Li S. Effect of saline water irrigation on soil development and plant growth in the Taklimakan desert highway shelterbelt. Soil and Tillage Research, 2015; 146(2): 99-107.

[4] Bani A, Daghari I, Hatira A, Chaabane A, Daghari H. Sustainable management of a cropping system under salt stress conditions (Korba, Cap-Bon, Tunisia). Environmental Science \& Pollution Research, 2020; 21(6): 110-117.

[5] Pang G, Zhang S, Xu Z. Effect of irrigation with brackish water on photosynthesis characteristics and yield of winter wheat. IOP Conference, 
2018; 170(5): 052030.

[6] Murtaza G, Ghafoor A, Qadir M. Irrigation and soil management strategies for using saline-sodic water in a cotton-wheat rotation. Agricultural Water Management, 2006; 81(1-2): 98-114.

[7] Patel D P, Das A, Kumar M, Munda G C, Ngachan S V, Ramkrushna G L, et al. Continuous application of organic amendments enhances soil health, produce quality and system productivity of vegetable-based cropping systems in subtropical eastern Himalayas. Experimental Agriculture, 2015; 51(1): 85-106.

[8] Yuan C F, Feng S Y, Wang J, Huo Z L, Ji Q Y. Effects of irrigation water salinity on soil salt content distribution, soil physical properties and water use efficiency of maize for seed production in arid northwest China. Int J Agric \& Biol Eng, 2018; 11(3): 137-145.

[9] Li L, Chen J, Wang S, Tan Y, Meng B, Zou G, et al. Utilization of biochar for a process of methane dry reforming coupled with steam gasification under microwave heating. Journal of Cleaner Production, 2019; 237(2): 117-188.

[10] Wang J, Sui B, Shen Y J, Meng H B, Zhao L X, Zhou H B, et al. Effects of different biochars on antibiotic resistance genes during swine manure thermophilic composting. Int J Agric \& Biol Eng, 2018; 11(6): 166-171.

[11] Elbashier M, Shao X, Ali A, Mohmmed A. Effect of digestate and biochar amendments on photosynthesis rate, growth parameters, water use efficiency and yield of Chinese melon (Cucumis melo L.) under saline irrigation. Agronomy, 2018; 8(2): 22.

[12] Šimon T, Kunzová E, Friedlová M. The effect of digestate, cattle slurry and mineral fertilization on the winter wheat yield and soil quality parameters. Plant Soil and Environment, 2015; 61(11): 522-527.

[13] Wang L L, Li W Z, Wang Z J, Wang Z W, Sui C, Li Y. Effects of digestate application depth on soil nitrogen volatilization and vertical distribution. Int J Agric \& Biol Eng, 2016; 9(5): 101-107.

[14] Elbashier M M. Influences of some amendments on soil properties and Chinese melon (Cucumis melo L.) growth under saline water irrigation. Hohai University, Nanjing, 2020.

[15] Fan L, Zhou X, Li Y, Ji L, Wu G, Li B, et al. The influence of effective microorganisms on microbes and nutrients in kiwifruit planting soil. Applied Sciences, 2016; 6(6): 168-180.

[16] Wang L K, Shao X H, Xu M, Chen S. Bioremediation of nitrogen- and phosphorus-polluted aquaculture sediment by utilizing combined immobilized effective microorganisms and sediment aeration technology. Int J Agric \& Biol Eng, 2019; 12(6): 192-201.

[17] Mashela P W. Role of effective microorganisms in efficacy of Nemarioc-AG phytonematicide on suppression of meloidogyne incognita and growth of tomato plants. Acta Agriculturae Scandinavica, Section B-Soil \& Plant Science, 2017; 67(2): 169-174.

[18] Kalaji H M, Cetner M D, Samborska L A, Lukasik I, Oukarroum A, Rusinowski S, et al. Effective microorganisms impact on photosynthetic activity of Arabidopsis plant grown under salinity stress conditions. Annals of Warsaw University of Life Sciences-Land Reclamation, 2016; 48(2): 153-163.

[19] Sultana R S, Mahabubur R, Rubaiyat A. Melon crops improvement through biotechnological techniques for the changing climatic conditions of the 21st century. International Journal of Genetics and Genomics, 2014; 2(3): 30-41.

[20] Visconti F, Salvador A, Navarro P, Paz J M D. Effects of three irrigation systems on 'Piel de sapo' melon yield and quality under salinity conditions. Agricultural Water Management, 2019; 226(2): 557-564.

[21] Da S, Dias N, Dantas d, Morais P L, Abrantes Sarmento J D. Nutrient solution salinity effect of greenhouse melon (Cucumis melon L. cv. Néctar). Acta Agronómica, 2018; 67(4): 517-524.

[22] Page A L, Miller R H, Keeney D R. Methods of soil analysis. Part 2. American Society of Agronomy. Soil Science Society of America,
Madison, WI, USA, 1982; 4(2): 167-179.

[23] Estefan G, Sommer R, Ryan J. Methods of soil, plant, and water analysis A Manual for the West Asia and North Africa Region, 2013; 3(11): 170-176.

[24] Akhtar S S, Andersen M N, Liu F. Biochar mitigates salinity stress in potato. Journal of Agronomy and Crop Science, 2015; 201(5): 368-378.

[25] Li L, Li J Y, Wang H H, Georgieva T, Ferentinos K P, Arvanitis K G, et al Sustainable energy management of solar greenhouses using open weather data on MACQU platform. Int J Agric \& Biol Eng, 2018; 11(1): 74-82.

[26] Graber E R, Harel Y M, Kolton M, Cytryn E, Silber A, David D, et al. Biochar impact on development and productivity of pepper and tomato grown in fertigated soilless media. Plant and Soil, 2010; 337(1): 481-496.

[27] Pan Y X, Yuan C F, Jing S Y. Simulation and optimization of irrigation schedule for summer maize based on SWAP model in saline region. Int $\mathrm{J}$ Agric \& Biol Eng, 2020; 13(3): 117-122.

[28] Ning S R, Zhou B B, Wang Q J, Tao W H. Evaluation of irrigation water salinity and leaching fraction on the water productivity for crops. Int $\mathrm{J}$ Agric \& Biol Eng, 2020; 13(1): 170-177.

[29] Sekar S, Hottle R D, Lal R. Effects of biochar and anaerobic digester effluent on soil quality and crop growth in Karnataka, India. Agricultural Research, 2014; 3(2): 137-147.

[30] Hajamor Z, Hashemi H, Bouri S. The consequences of saline irrigation treatments on soil physicochemical characteristics. Euro-Mediterranean Journal for Environmental Integration, 2018; 3(1): 22. doi: 10.1007/ s41207-018-0064-y

[31] Bachmann S, Wentzel S, Eichler - Löbermann B. Co-digested dairy slurry as a phosphorus and nitrogen source for Zea mays L. and Amaranthus cruentus L. Journal of Plant Nutrition and Soil Science, 2011; 174(6): 908-915.

[32] She D, Sun X, Gamareldawla A, Nazar E, Hu W, Edith K. Benefits of soil biochar amendments to tomato growth under saline water irrigation. Scientific Reports, 2018; 8(1): 14743. doi: 10.1038/s41598-018-33040-7

[33] Głąb T, Palmowska J, Zaleski T, Gondek K. Effect of biochar application on soil hydrological properties and physical quality of sandy soil. Geoderma, 2016; 281(1): 11-20.

[34] Herath H M, Camps A M, Hedley M. Effect of biochar on soil physical properties in two contrasting soils: an Alfisol and an Andisol. Geoderma, 2013; 209(1): 188-197.

[35] Głodowska M, Husk B, Schwinghamer T, Smith D. Biochar is a growth-promoting alternative to peat moss for the inoculation of corn with a pseudomonad. Agronomy for Sustainable Development, 2016; 36(1): 21-31.

[36] Hernández E, Melendez-Pastor L, Navarro-Pedreño J, Gómez I. Spectral indices for the detection of salinity effects in melon plants. Scientia Agricola, 2014; 71(4): 324-330.

[37] Colla G, Roupahel Y, Cardarelli M, Rea E. Effect of salinity on yield, fruit quality, leaf gas exchange, and mineral composition of grafted watermelon plants. HortScience, 2006; 41(3): 622-627.

[38] Shao Y L, Chen J N, Wang L K, Hou M M, Chen D L. Effects of fermented organic fertilizer application on soil $\mathrm{N}_{2} \mathrm{O}$ emission under the vegetable rotation in polyhouse. Environmental Research, 2021; 200: 11149.

[39] García-Caparrós P, Llanderal A, Lao M T. Effects of salinity on growth, water use efficiency, and nutrient leaching of three containerized ornamental plants. Communications in Soil Science and Plant Analysis, 2017; 48(10): 1221-1230.

[40] Khataar M, Mohammadi M H, Shabani F. Soil salinity and matric potential interaction on water use, water use efficiency and yield response factor of bean and wheat. Scientific Reports, 2018; 8(1): 2679-2791.

[41] Uzoma K C, Inoue M, Andry H, Fujimaki H, Zahoor A, Nishihara E. Effect of cow manure biochar on maize productivity under sandy soil condition. Soil Use and Management, 2011; 27(2): 205-212. 